\author{
Asian Development Policy Review \\ $\operatorname{ISSN}(e):$ 2313-8343 \\ $\operatorname{ISSN}(p): 2518-2544$ \\ DOI: $10.18488 /$ journal.107.2020.84.236.259 \\ Vol. 8, No. 4, 236-259. \\ (C) 2020 AESS Publications. All Rights Reserved. \\ URL: www.aessweb.com \\ check for
updates
}

\title{
TRANSMISSION OF INTERNATIONAL FINANCIAL SHOCKS: A CROSS COUNTRY ANALYSIS
}

\author{
iD Sanjay Kumar \\ Rout $^{1+}$ \\ Drushikesh \\ Mallick $^{2}$
}

\author{
${ }^{1,2}$ Centre for Development Studies, Prasanthnagar, Ulloor, \\ Thiruvananthapuram, Kerala, India. \\ 'Email:sanjayrout1992@gmail.com Tel: +918848338987 \\ 'Email:hrushi@.cds.ac.inTel: +919895981413
}

(A) Check for updates

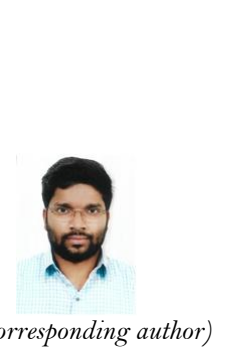

(+ Corresponding author)

\section{Article History \\ Received: 30 June 2020 Revised: 5 August 2020 Accepted: 9 September 2020 Published: 21 September 2020 \\ Keywords \\ Financial shocks spillover financial markets \\ Globalisation \\ Spillover channels \\ Diebold and Yilmaz spillover \\ method.}

\section{JEL Classification:} $\mathrm{E} 4 ; \mathrm{F} 3 ; \mathrm{F} 4$.

\begin{abstract}
This study measures the extent of cross-country financial shock spillover by utilizing Diebold and Yilmaz (2009); Diebold and Yilmaz (2012) method and using the impulse response function of the VAR model, it explores the important channel through which financial shocks transmit among the US, Japan, Germany, China, India, and Russia. The result shows that total financial shock spillover is $43.60 \%$, indicating that slightly more than two-fifths of the total variance of the forecast errors for six countries under consideration is explained by their shock spillover across countries. The finding is observed to be robust. Using the impulse response of the VAR model, we examined the relative importance of channels viz. financial, exchange rate, and trade. We observed that $46 \%$ of external financial shocks transmit to US through the financial channel, while it is predominantly the trade channel through which shocks transmit to Japan (43\%), Germany (43\%), and China (76\%). India receives major shocks $(74 \%)$ through exchange rate. Finally, trade and financial channels are important for Russia through which $76 \%$ of shocks come from external financial markets. The spillover is observed to be high which could be because of the increasing deregulation of financial markets including capital mobility in $21^{\text {st }}$ century.
\end{abstract}

Contribution/ Originality: This study contributes in four ways: (i) it considers both advanced and emerging economies, (ii) captures financial shocks through composite interest rate index (IRI), (iii) employs spillover method developed by Diebold and Yilmaz (2009); Diebold and Yilmaz (2012) and (iv) examines the contribution of channels which previous literature did not address.

\section{INTRODUCTION}

The cross-country financial shock spillover remains alive in the history of global economy. For instance, the Asian Financial Crisis (1997-98) and the Global Financial Crisis (2007-09) had the genesis in specific regions and

\footnotetext{
${ }^{1}$ Asian Financial Crisis (1997-98) alternatively called as Asian Contagion defined as a sequence of currency devaluation and other follow up of economic events that stared in 1997 and impacted many countries.

Global Financial Crisis (2007-09) began in 2007 from subprime mortgage market in the USA and took the turn of a great depression of 1930's. It advanced into full-

blown global banking crisis with the collapse of the Lehman Brother's Investment Bank in 2008.
} 
later on spread to several regions (Nier \& Merrouche, 2010). This implies that financial instability in one country causes instability in another country. With acceleration in the pace of global integration, the size of spillover between countries tends to be much higher in the $21^{\text {st }}$ century than earlier. A higher degree of globalization and market integration in $21^{\text {st }}$ century produces a larger size of spillover.

The economic result of financial shocks spillover is manyfold. This spillover not only inhibits the financial markets but also causes damages to the real economy. For instance, the shock spillover can make the financial markets more fragile, hamper exports, weaken investment and reduce employment, income levels, consumption demand, rising inequality, and reduce welfare of the people. Therefore, assessing the extent of financial shocks spillover and identifying the channels through which financial shocks transmit across countries is quite important and fundamental to internalizing the external shocks in $21^{\text {st }}$ century.

The present study captures financial shock through various rates of interest based on their maturity patterns. The current study presents the apt literature here concerning the interest rate spillover between countries. Many studies; Kirchgässner and Wolters (1987); Fujihara and Mougoué (1996); Ciner (2011); Căpraru and Ihnatov (2012); Hassler and Werkmann (2012); Chang and Yi (2015) and Caporale, Carcel, and Gil-Alana (2017) focus on advanced countries only. As a result, they tend to ignore the bidirectional spillover between advanced and emerging countries. They have also incorporated only short-term interest rates in exploring the cross-country spillover of interest rate shocks.

However, some other studies such as Hassler and Werkmann (2012); Sowmya, Prasanna, and Bhaduri (2016) dealt with various interest rates based on their maturity. Only a few studies stretched their analyses mainly covering developed economies to capturing a few emerging countries or the spillover between them. These studies include Chinn and Frankel (1995); Anoruo, Ramchander, and Thiewes (2002); Mohan and Nandwa (2009); Edwards (2010); Sowmya et al. (2016) and Feldkircher, Huber, Chantapacdepong, and Punzi (2017). The previous studies do not demonstrate any complete insight about how the financial shocks spillover and what is the extent of these spillovers across countries through various channels.

Therefore, this study aims to assess the extent and the relative importance of various channels in the transmission mechanism of financial shocks among a group of economies such as the US, Japan, Germany, China, India, and Russia, which are found to be prominently participating in the globalization process. The important concern for policymakers is to understand the extent of spillover and the relative role of channels via financial shock spillover. In this context, two important questions arise; (a) what is the extent of financial shock spillover from one region to another region? and (b) which one relatively constitutes an important channel through which financial shocks spillover from one region to another? These questions are addressed comprehensively in the present study. This is because, unveiling the extent of spillover and identifying the channels through which shocks spillover among different countries in a systematic way, can precisely strengthen our understanding for policy perspective.

Our sample consisting of the US, Japan, Germany, China, India, and Russia (a mix of both advanced and emerging countries) constitutes six large countries by the standards of purchasing power (PP). Their share of GDP together constitutes around $52 \%$ of the whole world, whereas the share of China, India, and Russia together forms around 30\% in total world GDP (by PP). Further, they have important relationships among them through financial (investment) and real transactions (goods and services exports and imports). The literature focuses unidimensionally on examining the transmission of shocks either from advanced to advanced countries alone or from advanced to developing economies but not in the reverse direction. Therefore, given the expanding nature and size of the markets of emerging economies like China, India, and the Russian Federation, this study tries to investigate whether emerging economies can influence the financial markets of advanced economies and thereby this study tries to contribute to the empirical literature in a modest way.

We developed a composite real interest rate index (IRI) through Principal Component Analysis (PCA) to capture financial shocks for each country. IRI incorporates real overnight, short-term, and long-term interest rates. 
A detailed explanation of IRI is provided in section 4. The idea behind IRI ${ }^{2}$ is that since various interest rates prevail based on their maturity pattern, a mix of various interest rates in ways of IRI would help us to track the overall size of spillover from one country to another. This is because, a single maturity interest rate, may not be able to reveal the exact cross-country spillover as financial transactions are carried over different maturities (overnight, short-run and long-run). Considering IRI as integrated characteristics of the financial market of individual economies, this study justifies its contribution to the literature. The findings of which may guide domestic and international investors in investing their capital in the international market and policymakers as well in tailoring their policies for macroeconomic stability and growth.

We examine the issue employing the time series VAR model. VAR model is a natural tool for macroeconomic analysis since it captures both contemporaneous links (Lütkepohl, 2011) and lagged information of series. It matters for uncovering the effects of cross-country financial shocks spillover. To look at the extent of spillover, we have employed Diebold and Yilmaz (2009); Diebold and Yilmaz (2012)3 method. This method is based on generalized forecast error variance decomposition of the h-step ahead forecast horizon of the VAR model. It also allows the forecast error variance of each variable into parts from the total shocks. The main advantage of Diebold and Yilmaz's method is that it summaries the spillover in a single number. So, it provides a summary of spillover effects in a table, reflecting the directional spillover and net spillovers, which are easy of interpretations. According to Urbina (2013) this method provides an assessment of spillover that not only stems from an unstable period but also from a stable period. To investigate the relative importance of different channels, we have also used a point estimate of impulse response function from a restricted form of VAR model.

This study contributes to the literature in many ways: First, it considers both developed and emerging economies. Second, we capture financial shocks by framing IRI through PCA. Third, we have employed Diebold and Yilmaz's method to measure the extent of spillover and impulse response of a restricted VAR model to capture the relative strength of channels through which shocks spillover or propagate. Fourth, it presents the theoretical maneuverability of channels that the existing studies do not address at all. Therefore, this study adds up value to the literature on the cross-country spillover of financial shocks.

The result shows the total extent of spillover reaches up to $43.60 \%$. The total spillover is quite high. This is because of the increasing deregulation of financial markets including capital mobility which causes larger spillover in the 21 st century. Further, we found on average, $46 \%$ of financial shocks spillover to the US through financial route. The importance of trade channel is also obvious from the presence of maximum external shocks, which is spreading to Japan, Germany, and China. Conversely, India's interest rate receives major external shocks through exchange rate channel. Finally, trade and financial channels are important for Russia through which more than $76 \%$ of shocks spillover from external sectors to Russia's financial market. Overall, this analysis provides some interesting empirical insights on cross-country spillover of financial shocks. This would give us a better sense of considering the implementation of proper macroeconomic policies in both the advanced and emerging economies' context.

The study is organized as follows: Section 2 briefly describes the related literature. Section 3 presents data description. Section 4 discusses about the construction of IRIs. Section 5 discusses the theoretical mechanism of channels. Section 6 presents the methodology of the study. Section 7 dovetails the estimated results and its interpretations, visualization of spillover, checks for the robustness, and empirical findings of transmission channels. And finally, section 8 concludes with policy.

\footnotetext{
${ }^{2}$ This is the first study that tried to capture aggregate real interest rates shocks transmission from one economy to another economy through various channels. The multivariate analysis like Principal Component Analysis has been used in making an aggregate interest rate index.

${ }^{3}$ Diebold and Yilmaz (2009); Diebold and Yilmaz (2012) rigorously analysed stocks, bond, exchange rate and commodities etc. volatility spillover across the U.S. assets markets.
} 


\section{RELATED LITERATURE}

The studies" based on cross-country spillover or linkages of interest rates (shocks) are limited. This study uses various interest rates to capture different dimensions of financial shocks based on their maturity. Therefore, we review the literature based on interest rate spillover only. So, examining the short-term interest rate linkage across seven newly industrialized markets in Asia, Japan, and the US, Anoruo et al. (2002) showed that interest rates within the Asian region responded well to one another. And there is a substantial increase in interest rates linkages among these markets over time. Mohan and Nandwa (2009) examined the interdependency between short-term nominal interest rates among ASEAN-5, China, and India. They noted the evidence of co-movement of interest rates of ASEAN-5 with China and India.

Some other studies such as Ciner (2011) analyzed the link between short-term interest rate of the US, German, UK, and Japan. They viewed that monetary policy innovations originating in Europe are quite important for the US money markets. But Edwards (2010) questioned the extent and speed of cross-country interest rate spillover, which relates to how the US's interest rate impacts the emerging countries' financial markets. Unlike the previous studies, he moved with the inclusion of emerging countries in his analysis. Further, Hassler and Werkmann (2012) analyzed short, medium, and long-term interest rates linkages for eleven OECD countries and the US. They found evidence of a strong linkage of German's interest rates with OECD countries. In contrast, Fujihara and Mougoué (1996) and Kirchgässner and Wolters (1987) claimed no international linkages of interest rates between advanced economies both in short-run and long run.

Further, incorporating the exchange rates, Frankel, Schmukler, and Serven (2004) estimated the short-term interest rate sensitivity consisting of 18 industrial and 29 developing countries. They came out with evidence of stronger transmission of interest rates under the fixed exchange rate regime than under a floating exchange rate regime. On the contrary, Căpraru and Ihnatov (2012) argued that spillover is higher under the floating exchange rate regime than intermediate and fixed exchange rates respectively. Takáts and Vela (2014) examined how monetary policy in advanced economies affects financial conditions of emerging markets through different channels. Such channels are short-term and long-term interest rates, exchange rates, and international bank lending rates. They strongly argued that the US monetary condition passes on to most emerging markets through short and long-term interest rates.

Chang and Yi (2015) reviewed the real interest rate parity condition by using modern tools such as sharp transition and smooth transition models. They evidenced the real interest rate parity condition mostly holds. Sowmya et al. (2016) analyzed the size and direction of spillover in sovereign bond yields across different maturities for the advanced and Asian countries. They found spillover is higher with a long-term rate than with short-term rates. This is because the long-term rate is preferred by international investors and the state of financial conditions. Feldkircher et al. (2017) investigated the international effects of positive and negative interest rates of European Economies on Asian Economies. They argued that when European monetary authority reduces the policy rate, it decreases both the short and long-term interest rates in Asia. And the effects on Asia are similar when interest rates are reduced to below zero by the European Monetary Authority. Therefore, the spillover is taking place between European countries and Asia under both positive and negative interest rate situation of the European countries.

In a study, Caporale et al. (2017) looked into the stochastic properties of the interest rate series and its long-run links. They found that the long-run link between interest rates reflects the globalization process and the increasing

\footnotetext{
${ }^{4}$. Fukao and Okubo (1984) opined that the international elements like foreign interest rates, expected change in the exchange rate and stock of current account surplus play a significant role in determining the domestic interest rates. The other early studies include; Goodwin and Grennes (1994); Mark (1985); Merrick Jr and Saunders (1986); Cumby and Mishkin (1986); Pigott (1993); Dutton (1993); Monadjemi (1997); Al Awad and Goodwin (1998); Artis and Zhang (1998) etc. Most of these studies have analysed the cointegrating relationship between interest rates of different countries.
} 
financial integration of the world. Finally, Probst (2019) examined whether the international or domestic force that settles national short-term real interest rates for 17 advanced economies. He observed two common international reasons that explain $50 \%$ of the variation in national real interest rates alone. Thus, it reflects the national real interest rate is elastic to global conditions during times of high international capital mobility.

\section{DATA DESCRIPTION}

Interest rate data set include overnight, short-term, and long-term interest rates ${ }^{5}$. Other data comprise of both exports and imports of goods and services (\%GDP), consumer price index (CPI) ${ }^{6}$, real effective exchange rate, and S\&P global equity indices of each country. The overnight, short-term, and long-term interest rates data are drawn from the OECD database. But India's short-run interest rate data is taken from "International Financial Statistics of International Monetary Fund". The long-term interest rate data for China, India, and Russia is taken from "Investing.com" with a daily frequency. The data on exports and imports of goods and services and S\&P Global Equity Indices are drawn from the "World Development Indicators of the World Bank". The statistics on real effective exchange rates are taken from Federal Reserve Economic Data (FRED) on a monthly frequency. The other data set such as on CPI are taken from the OECD data source with a quarterly frequency.

From the sources, the interest rate is available in nominal terms. We converted the nominal interest rate into a real interest rate by subtracting the inflation rate (CPI). We also converted the daily (long-term interest rate of China, India, and Russia) and monthly frequency statistics (real effective exchange rate) into quarterly frequency by taking their averages. The annual data (Trade data and S\&P Global Equity Indices data) is also converted into quarterly frequency data using the cubic spline interpolation method.

We have considered the logarithmic value of export and import and real effective exchange rates ${ }^{7}$ to remove outlier effects in the series. Finally, we have used all the quarterly frequency data in the model covering the period from 2000: Q1 to 2018: Q2. This study uses money market rates and secondary market interest rates as they are less regulated. These rates respond to one another with increasing financial market integration. These interest rates are important for spillover analysis since money and capital markets are integrating at a faster pace than any other market. Therefore, these indicators are suitable for spillover analysis. The S\&P global equity indices are treated as a financial channel variable. This is because it measures the general level of stock prices (both growth stocks and value stocks), so this can represent the financial market better than any other financial instrument.

\section{COMPOSITE INTEREST RATES INDEX (IRI)}

To build up an IRI index, the study uses a multivariate method known as principal component analysis (PCA). PCA is a multivariate data saving technique that is found to be useful for building up the composite index $(\mathrm{OECD} / \mathrm{JRC}, 2008)^{8}$. The principal component obtained from PCA would have a linear relation with the original data set. It gives a component matrix that holds as many principal units as many variables. This component matrix is normalized in the following way:

\footnotetext{
${ }_{5}^{5}$ The overnight interest rate defined as the rate of interest charged on less than 24-hour call money or interbank lending rate for all the countries. Short term interest rates refer to 3-month money market rates. Long term interest rates include quarterly yield on 10 years Government bond/securities.

${ }^{6}$ The consumer price index (CPI) is taken from the OECD data source with quarterly frequency. CPI is considered as to represent the price level for all the countries and the intuition behind using CPI as a measure of price level is that it covers prices in both goods and services comprehensively than any other measure of price levels.

${ }_{7}$ The real effective exchange rate (index $\left.2010=100\right)$ is defined as a weighted average of bilateral exchange rates adjusted by relative CPI (FRED) of countries. 8 OECD/JRC (2008). Handbook on constructing composite indicators: methodology and user guide. This handbook provides an extensive idea about how to frame a composite index involving various methods.
} 
Normalized value $=\frac{i^{\text {th }} \text { component }}{\sum_{i=1}^{\mathrm{n}} i}$

Where $i=1,2$ and 3 , and $n=3$ (three variables).

Since the present study considers incorporating three terms of interest rates based on their maturity patterns, it traces out three normalized values labeled as $w_{1}, w_{2}$ and $w_{3}$ for each country out of a total of six countries. The following Table 1 shows the component matrix and its normalized values.

Table 1. Component Matrix of IRI.

\begin{tabular}{c|c|c|c}
\hline Countries & Variables & P.Comp. & N. comp. \\
\hline \multirow{4}{*}{ US } & ROIR & 0.968 & 0.350 \\
\cline { 2 - 4 } & RSTIR & 0.961 & 0.348 \\
\cline { 2 - 4 } & RLTIR & 0.832 & 0.301 \\
\hline \multirow{4}{*}{ Japan } & ROIR & 0.978 & 0.335 \\
\cline { 2 - 4 } & RSTIR & 0.963 & 0.330 \\
\cline { 2 - 4 } & RLTIR & 0.974 & 0.334 \\
\hline \multirow{4}{*}{ China } & ROIR & 0.984 & 0.338 \\
\cline { 2 - 4 } & RSTIR & 0.981 & 0.337 \\
\cline { 2 - 4 } & RLTIR & 0.945 & 0.324 \\
\cline { 2 - 4 } & ROIR & 0.973 & 0.342 \\
\cline { 2 - 4 } & RSTIR & 0.901 & 0.316 \\
\hline \multirow{3}{*}{ India } & RLTIR & 0.969 & 0.340 \\
\cline { 2 - 4 } & RSTIR & 0.929 & 0.337 \\
\cline { 2 - 4 } & RLTIR & 0.849 & 0.308 \\
\hline \multirow{3}{*}{ Russia } & ROIR & 0.971 & 0.353 \\
\cline { 2 - 4 } & RSTIR & 0.857 & 0.415 \\
\cline { 2 - 4 } & RLTIR & 0.913 & 0.141 \\
\hline Extraction Method: Principal Component Analysis. & & 0.443 \\
\hline Note: P. comp is the principal component: N. comp is the normalized component. & \\
\hline
\end{tabular}

The normalized values in the component matrix are used as weights for making IRI for six countries, respectively. Therefore, it can capture all the important information in the data set without loss of any information. IRI is a linear combination of different terms of interest rates for each country and their normalized values would serve as weights as presented in Table 1 . Symbolically,

$$
I R I=W_{1} * R O I R+W_{2} * R S T I R+W_{3} * R L T I R
$$

Whereas, IRI = real composite interest rates index, ROIR $=$ Real overnight Interest Rate, RSTIR $=$ Real ShortTerm Interest Rate, RLTIR $=$ Real Long-Term Interest Rate, and $W_{1}, W_{2}$ and $W_{3}$ are weights according to normalized values in the component matrix. We use this index to find out how financial shocks of one country spillover to another country.

\section{WORKING OF INTERNATIONAL TRANSMISSION CHANNELS}

We considered three important channels: exchange rate channel, trade channel, and financial channel. The following are the theoretical interpretations of the contribution of each channel mechanisms.

Exchange Rate Channel: The exchange rate channel is based on the idea of demand substitution for goods between home and foreign countries. The higher is the interest rate at home may attract capital and lead to an appreciation of home country's currency. This appreciation of exchange rate makes imports cheaper and exports 
dearer. It may in turn alter the composition of world demand by diverting demand away from home goods to foreign goods under a flexible exchange rate system. Therefore, to meet this increased demand, investors from foreign countries need to raise financial capital from their markets and augment their production levels. Once the demand for capital goes up in foreign country, it can affect their interest rate or financial market.

Trade Channel: Trade channel works with the idea that higher is the interest rate in home country, which may lead to lowering of investment, income, and less demand for imports or reducing the outlays in home country. This decline in home country's economic activities may lead to lessening of economic activities in foreign country through trade channels (by reducing home country's demand for imported goods and services). In turn, it would distort the equilibrium position between the demand for and supply of capital or funds for economic activities in foreign country. This, in turn, may impact the interest rate in foreign countries.

Financial Channel: Besides exchange rate and trade channels, financial channel is based on the idea that an increase in the interest rate in home country changes the financial asset composition under the possession of international investors. When prices of financial assets (like equity prices) and liabilities alter because of higher interest rate in home country, affects interest rate in foreign countries. The importance of financial channel depends on the degree of market integration and market liberty which provides equal opportunity for both domestic and foreign investors.

\section{METHODOLOGY}

\subsection{Method to Estimate the Extent of Spillover}

To measure the extent of spillover, we have employed Diebold and Yilmaz ${ }^{9}$ spillover method. It is based on generalized forecast error variance decomposition of the h-step ahead forecast horizon of the VAR model. The variance decomposition allows the forecast error variance of each variable into parts from total shocks.

Alternatively, it allows us to estimate the fraction of h-step ahead error variance for forecasting $Z_{i}$ which is due to

$Z_{j}, \forall j \neq i$ for each $i$. Diebold and Yilmaz (2009); Diebold and Yilmaz (2012) recommended an application of generalized VAR model of Koop, Pesaran, and Potter (1996) and Pesaran and Shin (1998). The generalized VAR model provides the order invariant variance decomposition parameters. This generalized method allows correlation between shocks but reckons them using the past observed distribution of shocks.

The own variance share indicates a fraction of h-step ahead error variance in forecasting $Z_{j}$ due to shocks in $Z_{j}$, for $j=1,2,---\mathrm{N}$, and cross variance share represents the fraction of h-step ahead error variances in forecasting $Z_{j}$ due to shocks in $Z_{i}$, for $i_{j} j=1,2,-----N$ where $i \neq j$. The Diebold and Yilmaz (2009); Diebold and Yilmaz (2012) method of estimation represents a spillover table which is fundamental to understanding various spillover measures. We can estimate the size of the spillover from Table 2 as well. The $\mathrm{N} \times$ $\mathrm{N}$ block in the following Table 2 known as variance decomposition matrix noted as $\left[T_{i j}^{h}\right]$.

${ }_{9}$ Diebold and Yilmaz (2009); Diebold and Yilmaz (2012) rigorously analysed stocks, bond, exchange rate and commodities etc. volatility spillover across the U.S. assets markets 


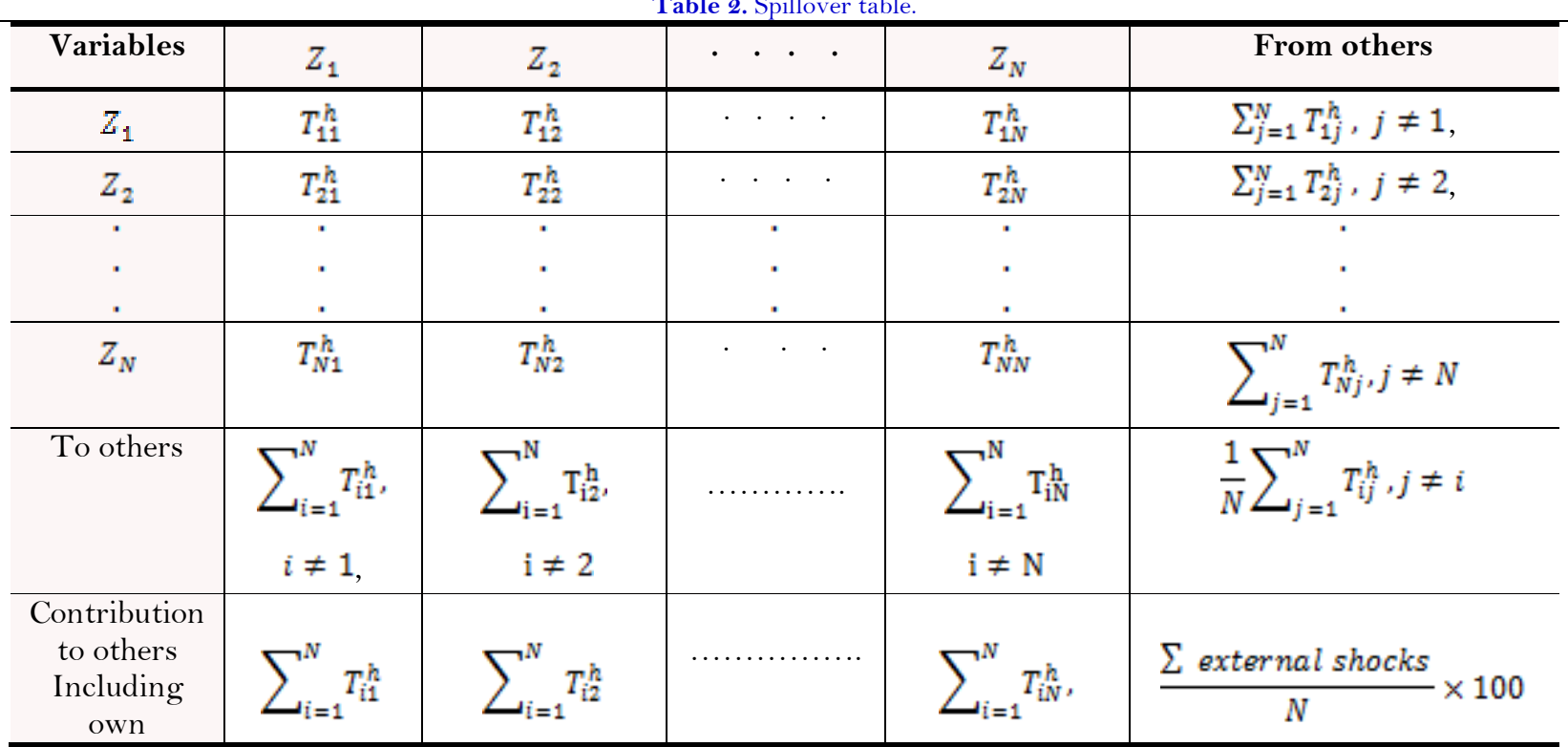

The elements in the second last bottom row (named as 'To others' in Table 2) represent column sums except for own (diagonal) element in that column. The rightmost column (named as 'from others') represents row sum, except for own element in that row and a bottom right element represents a total average. This spillover measure includes its own shocks and shocks from others. The diagonal elements represent own shocks. Off-diagonal elements represent shocks from other in the variance decomposition matrix. Table 2 represents IRI shocks spillover among different countries. Marking the KPPS (Koop et al., 1996) h-step ahead forecast error variance decomposition by $\Theta_{j i}^{g}(\mathrm{~h})$, for $\mathrm{h}=1,2$,

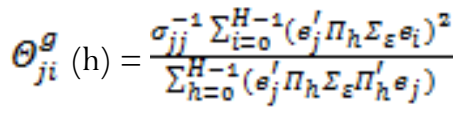

Where $\Sigma$ is a variance matrix for error vector ' $\varepsilon, \sigma_{j j}$ is a standard deviation of error term for $j^{\text {th }}$ equation, $e_{j}$ is the selection vector with one as $j^{\text {th }}$ element and zero otherwise in Equation 1. It can be given by $\sum_{i=1}^{N} \Theta_{j i}^{g}(h)$ $\neq 1$, which means a sum of elements of each row of variance decomposition table is not equal to 1 . This is because of non-zero covariance between original shocks. Now, we can normalize $\Theta_{j i}^{g}(\mathrm{~h})$ by dividing it by row sum in Equation 1 and can be reduced as in Equation 2:

$$
\widehat{\Theta}_{j i}^{g}(\mathrm{~h})=\frac{\sigma_{j i}^{g}(h)}{\sum_{i=1}^{N} \sigma_{j i}^{g}(h)}
$$

\footnotetext{
${ }_{10}$ The Equation 1 is derived from generalised impulse response function. For details, one can follow Koop et al. (1996) and Pesaran and Shin (1998) papers
} 
By construction $\sum_{i=1}^{N} \widehat{\Theta}_{j i}^{g}(h)=1$ and $\sum_{j i=1}^{N} \widehat{\Theta}{ }_{j i}^{g}(h)=\mathrm{N}$ in Equation 2

The spillover index is the cross-variance shares gained from the table and marked as:

$$
\begin{aligned}
& \sum_{j i=1}^{N} \widehat{\theta} \frac{g}{j i}(h) \quad \sum_{j i=1}^{N} \widehat{\theta} \frac{g}{j i}(h) \\
& S^{g}(\mathrm{~h})=\frac{j \neq i}{\sum_{j i=1}^{N} \hat{\theta} \frac{g}{j i}(h)} \times 100=\frac{j \neq i \in}{N} \times 100
\end{aligned}
$$

Like Cholesky factor-based measure of KPSS used in Diebold and Yilmaz (2009); Diebold and Yilmaz (2012). Equation 3 shows the total spillover index of IRI to the total forecast error variance of IRI, which is because of mutual contact among countries. Diebold and Yilmaz estimate the size of spillover received by market $j$ from all other markets $i$ which is expressed in the following Equation 4:

$$
S_{j *}^{g}(\mathrm{~h})=\frac{\sum_{i=1}^{N} \widehat{\hat{\theta}} \frac{g}{j \neq i}(h)}{\sum_{i=1}^{N} \widehat{\theta} \frac{g}{j i}(h)} \times 100
$$

Similarly, the size of spillover from the market $j$ to all other markets $i$ can be expressed in the following Equation $5:$

$$
S_{* j}^{g}(h)=\frac{\sum_{i=1}^{N} \widehat{\theta} \frac{g}{i j}(h)}{\sum_{i=1}^{N} \widehat{\theta} \theta_{i j}^{g}(h)} \times 100
$$

Note that spillover size provides a decomposition of total spillover into those coming from (or to) a particular source as mentioned in Equation 4 and Equation 5. The estimation procedure of net spillover from market $j$ to all other markets $i$ (that is, Equation 5 minus Equation 4) and can be expressed in the form of Equation 6 as follows:

$$
S_{j}^{g}(\mathrm{~h})=S_{i j}^{g}(\mathrm{~h})-S_{j i}^{g}(\mathrm{~h})
$$

Equation 6 indicates the net spillover which is the difference between gross shocks spillover to (that is Equation 5) and gross spillover received from all other markets (that is Equation 4). It is to be noted that all the variables in the model are endogenous.

\subsection{Method to Identify the Channels}

To look into the importance of different channels, we used a point estimate of the orthogonal impulse response of restricted VAR model. Here, shocks coming from k variables are not distorted by any other shocks due to the orthogonalized assumption. The optimum lag in the restricted VAR model is 3 chosen according to the Schwarz Information Criteria (SIC). The restricted VAR (3) contains two countries' (A and B) main variables; IRI and channel variables; trade, exchange rate, and financial channels variables simultaneously.

The orthogonal impulse response is sensitive to the ordering of variables. Therefore, the order has been done by placing a large country's variable at first, then variables of the second large country in the model. For instance, between the US and Japan, it places the US's variables in the first place, then Japan in second place. This is because 
the US is larger than Japan by market size. Bayoumi and Swiston (2009) suggest that orthogonal impulse response function ${ }^{11}$ works well if the ordering of the variables is clear. The two models are displayed in the following in Equation 7 \& Equation 8.

$$
\left[\begin{array}{l}
X_{1} \\
X_{2} \\
X_{2} \\
X_{4} \\
X_{5} \\
X_{6} \\
X_{7} \\
X_{9}
\end{array}\right]=\left[\begin{array}{l}
C_{1} \\
C_{2} \\
C_{2} \\
C_{4} \\
C_{5} \\
C_{6} \\
C_{7} \\
C_{g}
\end{array}\right]+\left[\begin{array}{cccccccc}
0 & a_{12} & a_{13} & a_{14} & 0 & 0 & 0 & 0 \\
0 & 0 & 0 & 0 & a_{25} & 0 & 0 & 0 \\
0 & 0 & 0 & 0 & a_{35} & 0 & 0 & 0 \\
0 & 0 & 0 & 0 & a_{45} & 0 & 0 & 0 \\
0 & 0 & 0 & 0 & 0 & 0 & 0 & 0 \\
0 & 0 & 0 & 0 & 0 & 0 & 0 & 0 \\
0 & 0 & 0 & 0 & 0 & 0 & 0 & 0 \\
0 & 0 & 0 & 0 & 0 & 0 & 0 & 0
\end{array}\right]\left[\begin{array}{l}
X_{1 t-1} \\
X_{2 t-1} \\
X_{a t-1} \\
X_{4 t-1} \\
X_{5 t-1} \\
X_{6 t-1} \\
X_{7 t-1} \\
X_{8 t-1}
\end{array}\right]+\left[\begin{array}{cccccccc}
0 & a_{12} & a_{12} & a_{14} & 0 & 0 & 0 & 0 \\
0 & 0 & 0 & 0 & a_{25} & 0 & 0 & 0 \\
0 & 0 & 0 & 0 & a_{35} & 0 & 0 & 0 \\
0 & 0 & 0 & 0 & a_{45} & 0 & 0 & 0 \\
0 & 0 & 0 & 0 & 0 & 0 & 0 & 0 \\
0 & 0 & 0 & 0 & 0 & 0 & 0 & 0 \\
0 & 0 & 0 & 0 & 0 & 0 & 0 & 0 \\
0 & 0 & 0 & 0 & 0 & 0 & 0 & 0
\end{array}\right]\left[\begin{array}{l}
X_{1 t-2} \\
X_{2 t-2} \\
X_{3 t-2} \\
X_{4 t-2} \\
X_{5 t-2} \\
X_{6 t-2} \\
X_{7 t-2} \\
X_{8 t-2}
\end{array}\right]+
$$

$$
\left[\begin{array}{cccccccc}
0 & a_{12} & a_{13} & a_{14} & 0 & 0 & 0 & 0 \\
0 & 0 & 0 & 0 & a_{25} & 0 & 0 & 0 \\
0 & 0 & 0 & 0 & a_{35} & 0 & 0 & 0 \\
0 & 0 & 0 & 0 & a_{45} & 0 & 0 & 0 \\
0 & 0 & 0 & 0 & 0 & 0 & 0 & 0 \\
0 & 0 & 0 & 0 & 0 & 0 & 0 & 0 \\
0 & 0 & 0 & 0 & 0 & 0 & 0 & 0 \\
0 & 0 & 0 & 0 & 0 & 0 & 0 & 0
\end{array}\right]\left[\begin{array}{l}
X_{1 t-a} \\
X_{2 t-a} \\
X_{3 t-a} \\
X_{4 t-a} \\
X_{5 t-a} \\
X_{6 t-a} \\
X_{7 t-a} \\
X_{3 t-a}
\end{array}\right]+\left[\begin{array}{l}
u_{1 t} \\
u_{2 t} \\
u_{3 t} \\
u_{4 t} \\
u_{5 t} \\
u_{6 t} \\
u_{7 t} \\
u_{8 t}
\end{array}\right]
$$
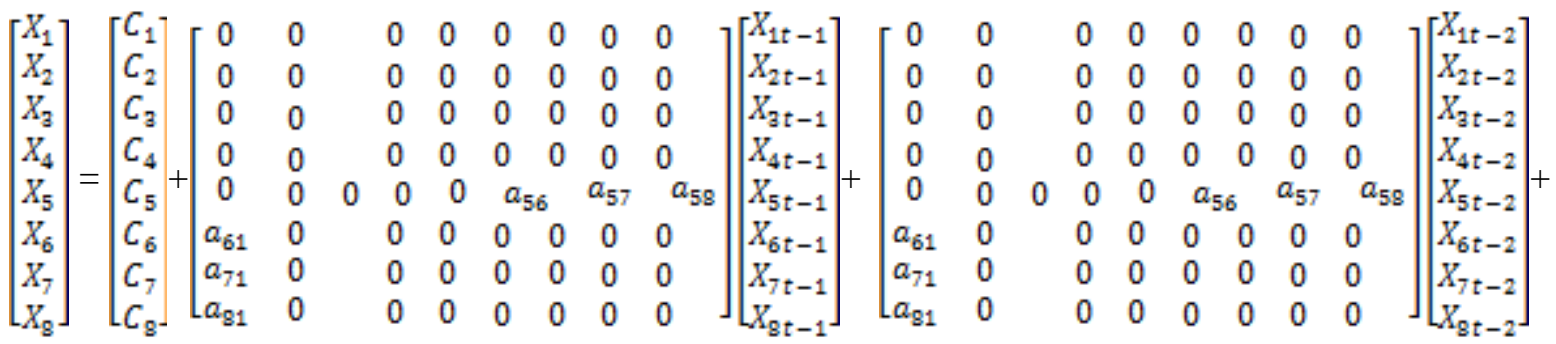

$$
\left[\begin{array}{ccccccccc}
0 & 0 & 0 & 0 & 0 & 0 & 0 & 0 \\
0 & 0 & 0 & 0 & 0 & 0 & 0 & 0 \\
0 & 0 & 0 & 0 & 0 & 0 & 0 & 0 \\
0 & 0 & 0 & 0 & 0 & 0 & 0 & 0 \\
0 & 0 & 0 & 0 & 0 & a_{56} & a_{57} & a_{58} \\
a_{61} & 0 & 0 & 0 & 0 & 0 & 0 & 0 \\
a_{71} & 0 & 0 & 0 & 0 & 0 & 0 & 0 \\
a_{91} & 0 & 0 & 0 & 0 & 0 & 0 & 0
\end{array}\right]\left[\begin{array}{l}
X_{1 t-a} \\
X_{2 t-a} \\
X_{3 t-a} \\
X_{4 t-a} \\
X_{5 t-a} \\
X_{6 t-a} \\
X_{7 t-a} \\
X_{8 t-a}
\end{array}\right]+\left[\begin{array}{l}
u_{1 t} \\
u_{2 t} \\
u_{3 t} \\
u_{4 t} \\
u_{5 t} \\
u_{6 t} \\
u_{7 t} \\
u_{8 t}
\end{array}\right]
$$

Where $X_{1}$ is the IRI of country A, $X_{2}$ is the EXIM (i.e. trade channel) of country A, $X_{3}$ is the S\&P Global Equity Index (i.e. Financial channel) of country A, $X_{4}$ is the real effective exchange rate (i.e. exchange rate channel) of country A, $X_{5}$ is the IRI of country B, $X_{6}$ is the EXIM (i.e. trade channel) of country B, $X_{7}$ is the S\&P Global

\footnotetext{
${ }_{11}$ An IRF estimates the time profile of the effect of shocks or innovation at a given point in time on the expected future values of the variables in a dynamical system (Koop et al. (1996) and Pesaran and Shin (1998))
} 
Equity Index (that is Financial channel) of country B and $X_{\mathrm{g}}$ is the real effective exchange rate (i.e. exchange rate channel) of country B. Note that variables are the same in both Equation 7 and Equation 8.

Only two countries are considered at a time while estimating the model. The properties of endogenous variables and error terms are assumed to be similar as is the case with the unrestricted VAR model. However, Equation 7 shows how shocks are passed on from B to A through trade, financial, and exchange rate channels. Similarly, Equation 8 shows how shocks spillover from A to B through trade, financial, and exchange rate channels. More precisely, other things being equal, when one standard deviation shock is given to IRI $\left(\boldsymbol{X}_{5}\right)$ in $\mathrm{B}$, affects IRI ( $X_{1}$ and showed by $\left.a_{12}\right)$ in A through trade route $\left(X_{2}\right.$ and marked by $\left.a_{25}\right)$ of A. All other coefficients in the model take the value zero to ensure that the shocks come to A from B via trade channel. Similarly, when one standard deviation shock is given to IRI $\left(X_{5}\right)$ in $\mathrm{B}$, affects IRI $\left(X_{1}\right.$ and marked by $\left.a_{13}\right)$ in A through the financial channel $\left(X_{3}\right.$ and marked by $\left.a_{35}\right)$ of A. Finally, when one standard deviation shock is given to IRI $\left(X_{5}\right)$ in B, it affects IRI $\left(X_{1}\right.$ and marked by $\left.a_{14}\right)$ in A through the exchange rate channel ( $X_{4}$ and marked by $\left.a_{45}\right)$ of A (See Equation 7 ).

Equation 8 shows when one standard deviation shock is given to IRI $\left(X_{1}\right)$ in A, it affects IRI $\left(X_{5}\right.$ and marked by $\left.a_{56}\right)$ in $\mathrm{B}$ via trade channel $\left(X_{6}\right.$ and marked by $\left.a_{61}\right)$ of $\mathrm{B}$ and similar process follows for the financial and exchange rate channels through which B receives shocks from A. This way we capture the role of a particular channel without receiving any disturbance from other variables at the same time. This helps us to decompose total shocks into shocks through trade, finance, and exchange rate channels respectively.

To understand comprehensively these channels, see theoretical interpretation mentioned in section 5 . We have estimated the orthogonal impulse response function under a restricted VAR model. This orthogonalized impulse response is used to see the relative share of each channel in the international spillover of financial shocks. This has been evaluated by point estimation of the orthogonal impulse response function over eight horizon quarters and then we summed up the point estimates over eight-point estimates for each of the channels separately. After obtaining these summed up point estimates, the study has normalized the point estimate values to represent the relative contribution of each channel. Before estimation, the study examines the properties of the time series of all series $^{12}$.

\section{RESULTS AND DISCUSSION}

\subsection{Discussion for the Extent of Spillover}

The estimated model is found to be stable (see Figure A1 in Appendix). From Table 3, the total spillover reaches up to $43.60 \%$. In fact, increasing liberalization of financial markets and progressive mobility of capital contribute to this high degree of financial shocks spillover. The diagonal elements in Table 3 (marked as bold) document the own IRI shocks of respective countries. It displays much higher shock for India, China followed by advanced economies such as Japan, Germany, the US, and then Russia to a lower extent. This implies that the

\footnotetext{
${ }_{12}$ The study examines the properties of the time series of all the data set by conducting the seasonality test, unit root test and structural break test and the result is presented in the appendix.
} 
financial markets of India and China are less connected with global economies compared to Russia, the US, Japan, and Germany. Examining the IRI shocks received by advanced countries from others, it shows that the US receives the highest magnitude of shocks, followed by Germany and Japan. The US has the characteristics of a developed, liquid, and efficient financial market in the world (Forbes, 2010). Thus, it tends to attract a greater magnitude of shocks from abroad. Japan also controls an important chunk of international reserves reflecting the intensive degree of integration of Japan with the global economy.

The emerging countries like Russia receive the highest amount of IRI shocks and then followed by China and to some extent India. Russia accounts for major spillover from external IRI shocks. It may be because; Russia's financial market is one of the biggest emerging markets like Germany by the size of its market capitalization. It provides a strong relationship between the Russian market and global financial markets (Jalolov \& Miyakoshi, 2005).

Table-3. Financial markets spillover table.

\begin{tabular}{c|c|c|c|c|c|c|c}
\hline Variables & US & Japan & Germany & China & India & Russia & From Others \\
\hline US & 44 & 12.3 & 19.1 & 14.3 & 6.9 & 3.4 & 56 \\
\hline Japan & 10.5 & 55.4 & 9.6 & 6.6 & 13.4 & 4.4 & 44.6 \\
\hline Germany & 20.1 & 10.3 & 54.8 & 3.9 & 1.1 & 9.7 & 45.2 \\
\hline China & 12.7 & 6.5 & 5.2 & 64.1 & 10.6 & 0.9 & 35.9 \\
\hline India & 2.4 & 4.8 & 3.8 & 8.1 & 76.2 & 4.7 & 23.8 \\
\hline Russia & 6.7 & 9.9 & 26 & 7.1 & 6.7 & 43.6 & 56.4 \\
\hline to others & 52.4 & 43.8 & 63.7 & 40.1 & 38.7 & 23.2 & \\
\hline including own & 96.5 & 99.2 & 118.5 & 104.2 & 114.9 & 66.8 & Total $43.60 \%$ \\
\hline Net & -3.6 & -0.8 & 18.5 & 4.2 & 14.9 & -33.2 & \\
\hline
\end{tabular}

Note: Spillover Table 3 is estimated by Diebold and Yilmaz method. It is based on generalized forecast error variance decomposition of 10 quarters ahead horizon with optimum lag 3 . The column-wise reading of figures reflects the spillover originating from countries given in columns to countries mentioned in rows. Alternatively, figures in rows reflect shocks received by countries in rows from countries in columns.)

In contrast, examining IRI shocks stemming from countries and spillover to others, it shows that Germany produces the highest degree of shocks and then followed by the US and Japan. This reveals the predominance of financial markets of advanced countries in the global financial markets. Goodwin and Grennes (1994); Cumby and Mishkin (1986); Al Awad and Goodwin (1998) and Chang and Yi (2015) show a strong interest rate link among advanced countries. This signifies the role of progressive mobility of capital. Thus, shocks of advanced countries spillover to other countries to a higher extent. Likewise, China makes a larger size of IRI shocks for others and then followed by India and Russia. It implies that with faster economic development and gradual liberalization of capital account, other economies are integrating with China. In turn, China impacts other countries' IRI to a greater extent.

The advanced countries play out a greater role in influencing IRI of others than some of emerging financial markets, which most often dominate the markets in terms of generation of their shocks on others. This implies that the advanced countries still play a leading role in passing their interest rates shocks to emerging countries. In turn, this affects the macroeconomic stability particularly the financial stability of the emerging economies. It has practical implications for emerging countries questioning their macroeconomic stability and policy credibility for almost over the last two decades. Thus, United Nation (2019) rightly noticed that external aspects expose domestic vulnerability and raise volatility in financial markets especially in emerging countries. As the discussion relates to the financial sector, in this context, Davydov and Vähämaa (2013) pointed out that the financial crisis spread to emerging markets to a larger extent. It happens due to capital flows with the advent of emerging market's economic position in the global economy (Bastidon, Bordo, Parent, \& Weidenmier, 2019). This occurs because more profit opportunities exist in emerging markets or favorable investment policies which attract investors from other advanced markets to invest in emerging countries. However, this also demonstrates that the US's and other advanced countries' dominant influence on the global financial markets is conspicuous. 
Net shocks of Germany, India, and China are found to be positive and reach at $18.5 \%, 14.9 \%$, and $4.2 \%$ respectively. It implies that the spillover of IRI shocks is greater from these countries compared to what they receive from others. In contrast, net spillover for Russia (-33.2\%), US (-3.6\%), and Japan (-0.8\%) are negative implying these countries' interest rates influence others less relative to other countries' influence on them.

\subsection{Visualisation of Spillover}

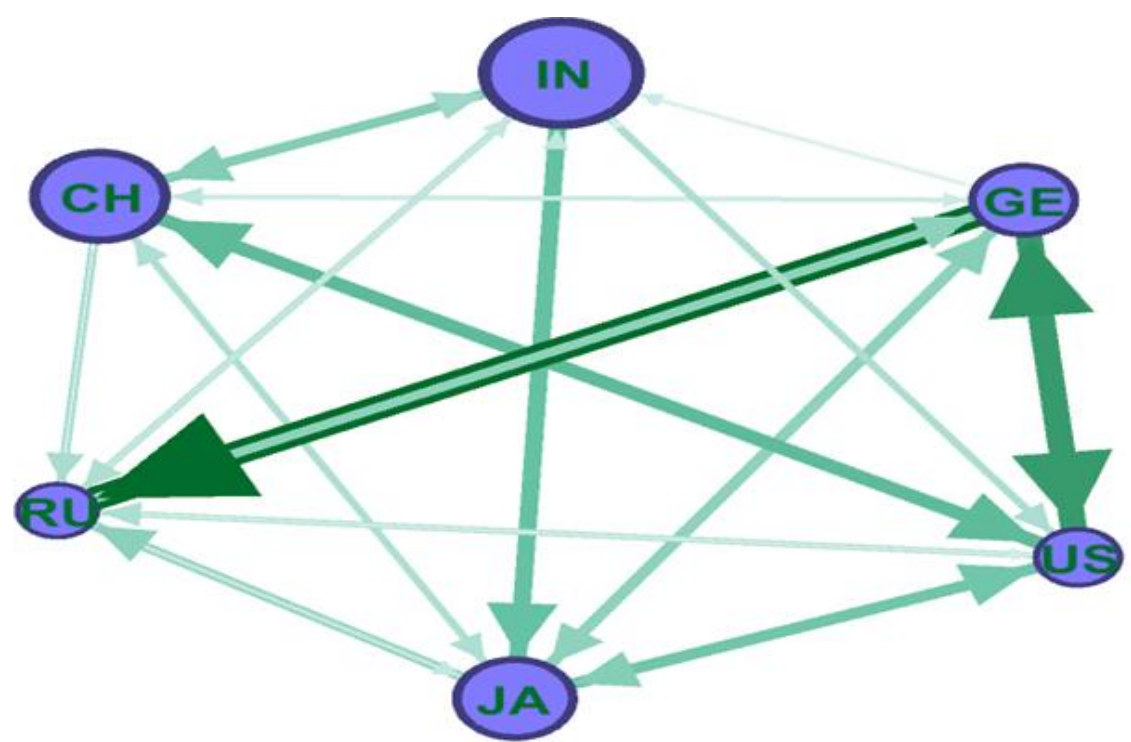

Figure-1. Visualising the financial shocks spillover

Figure 1 shows pairwise directional spillover of IRI shocks. It shows bidirectional spillover among countries. Circles in a figure are known as nodes. Bigger is the node, higher is the own IRI shocks and lesser is the external IRI shocks. Smaller is the node, higher is the external IRI shocks and lesser is the own IRI shocks. The connectivity lines in the figure are known as edges. Higher is the visibility of edges, larger is the degree of spillover and lesser is the visibility of edges, lower is the degree of spillover between countries. This figure is based on Table 3).

The pair-wise spillover reveals that IRI shocks spillover from the US to Germany (20.1\%), to China (12.7\%), to Japan (10.5\%) are higher in degree. The US is having the characteristics of a developed, liquid, and efficient financial market in the world (Forbes, 2010). Hence, passing a higher magnitude of financial shocks abroad seems to be on the expected line. Further, according to Goodwin and Grennes (1994); Cumby and Mishkin (1986) and Chang and $\mathrm{Yi}$ (2015), there is a stronger interest rate linkage between the US and other advanced economies. Similarly, it is in correspondence with what has been argued by Edwards (2010) and Takáts and Vela (2014) that the US passes its interest rate shocks to most of the emerging market economies.

The IRI shocks spread from Japan to the US (12.35), to Germany (10.3\%), to Russia (9.9), then from Germany to the US $(19.1 \%)$, to Russia (26\%), to Japan (9.6\%). These country-pairs are interlinked to a larger extent. Japan influences the US through the financial channel. This is because of the strong presence of Japanese investors in the US. Thus, there is a greater capital flow from Japan to the US (Cooper, 2013). Also, Cooper (2013) also found from his study that the volume of foreign capital between the US and Japan exceeds their volume of trade. The IRI shocks spillover from China to US (14.3), to India (8.1\%), then from India to Japan (13.4\%), to China (10.6\%), then from Russia to Germany (9.7\%) are important. In common expression, the world has recognized the major role of China in international trade (Bataa, Osborn, \& Sensier, 2018). Thus, shocks from China to foreign may spillover through trade and financial channels. 
India's real exchange rate is volatile and sensitive to external factors overtime (Kotai, 2013). So, the exchange rate channel worsens India's financial markets. Exchange rate uncertainties affect India's exports, current account balance, and domestic private sector investment (Dhasmana, 2017; Panda \& Mohanty, 2015). Finally, Russia transmits its shocks to Germany. Russia's financial market is also one of the biggest emerging markets like Germany by its size of market capitalization. It provides a strong relationship between the financial markets of Russian and Germany (Jalolov \& Miyakoshi, 2005).

\subsection{Robustness Checks}

We framed an alternative model by adding some important financial variables to the main model to check the robustness of our empirical findings. The other variables include CPI, log real effective exchange rate, and S \& P global equity indices. Such variables are sensitive to cross-country spillovers. Finally, we run PCA to get a single series. In the model, the PCA score of six countries is used and all the series in the model are treated as endogenous. The re-estimated model is observed to be stable (see Figure A2 in Appendix) and is similar in findings with the preceding estimated results.

Table A1 in the appendix shows $45.50 \%$ (total spillover) of forecast error variance as a result of the mutual spillover of their financial shocks. The financial markets in emerging economies receive a higher size of external shocks. This finding follows the argument advanced by the United Nation (2019)'s report. The report has rightly observed that external aspects expose domestic vulnerability and raise the volatility of financial markets more especially in emerging countries.

The US, Japan, and Germany receive shocks by $44.6 \%, 41.7 \%$, and $35.2 \%$ respectively from the external markets. These are lower even compared to emerging economies. In contrast, examining financial shocks stemming from countries and passing to others, it shows that the US and Japan generate and transmit the highest degree of shocks than China, India, and Russia. This reveals the predominance of financial markets of advanced countries in the global financial markets. Similarly, among the emerging countries, China and India cause a larger size of innovations for others, and then it is followed by Russia.

Overall summary: Table 3 is based on IRI while Table A1 (in the Appendix) includes IRI plus some important financial macroeconomic variables. The total spillover remains nearly the same although the results of the later estimated model show slightly higher than the estimated result of the former model. The insights gained here indicate that our analysis is robust and strongly argues that more than $43 \%$ of forecast error variance being explained by the mutual interactions among six large financial markets. Contrasting with other studies, our finding shows a slightly higher degree of spillover than the analysis carried out by Ahmad, Mishra, and Daly (2018). They found that return and volatility spillover among BRICS, the US, EMU, and Japan reaches up to $33.40 \%$ and $33.20 \%$ respectively.

\subsection{Discussion on Channels of Transmission of Shocks}

After observing high financial shock transmission among the countries under consideration, it is important to measure the role of various channels through which shocks are transmitted to the IRI of individual countries. Fig. 2 demonstrates that on an average $46 \%$ of the external IRI shock spillover to the US is propagated via financial channels. This may be because of the fact that the US is having the characteristics of a developed, liquid, and efficient financial market in the world (Forbes, 2010) ${ }^{13}$, which is responsible for attracting a higher size of shocks from abroad. Following the financial channel, the second important channel is the exchange rate channel that plays even a crucial role for the US. This is because substantial amounts of shocks (29\%) generated from all other countries except China spread to the US, which is enormous and remarkable in size. It may establish the point that

${ }^{13}$ Forbes (2010) has investigated that why do foreigners invest in the United States? 
the greater is the financial linkages, the greater is the role of the exchange rate. Therefore, the US receives a higher magnitude of shocks through financial and exchange rate channels. In contrast, the contribution of the trade channel is modest.

A meaningful contribution or sizeable percentage of shocks comes from all individual countries to the US's financial market through the financial channel. But in the common international policy discussion domain, the world has recognized the major role of China in international trade (Bataa et al., 2018)14. Thus, shock from China's IRI to US's IRI majorly occurs through the trade channel (55\%), while the rest of its shock to the US is passed through the financial channel (43\%). For Japan, both the exchange rate $(54 \%)$ and financial (44\%) channels play important roles in the spillover of shocks to the US. Japan influences the US's financial market through the exchange rate and financial channels. This could be because of relatively a greater presence of Japanese investors in the US market and capital outflows from Japan to the US (Cooper, 2013) ${ }^{15}$. Eventually, the US policymakers need to keep an eye on both financial and exchange rate channels through which external shocks are transmitted to the US.

\section{COUNTRIES'IRI->CHANNELS->US'S IRI}

\section{Trade Channel Exchange Rate Chennel E Financial Channel}
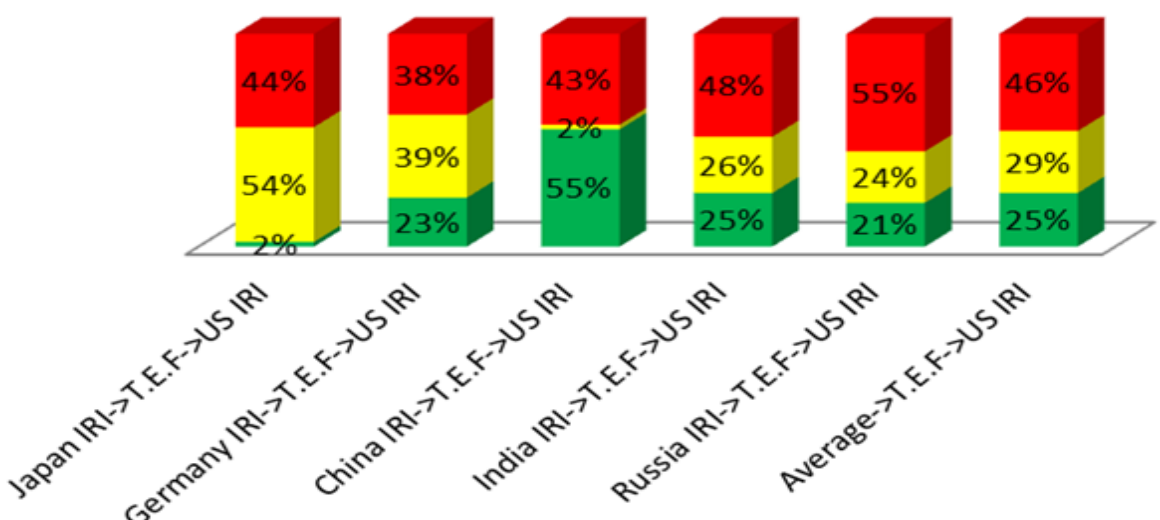

Figure-2. Financial shocks spillover to the US ${ }^{16}$.

Note: Figure 2 shows IRI shocks spillover from Japan, Germany, China, India, and Russia to the US via financial (F), the exchange rate $(\mathrm{E})$, and trade $(\mathrm{T})$ channels. Each column in the figure shows IRI shocks spillover from a particular country to the US via three channels. Also, we estimated the average shock spillover through three channels shown in the extreme right column in the above Fig.2.

The Figure 2 reflects the point estimate of the orthogonal impulse response from a restricted 8 variable VAR (3) model with $95 \%$ confidence interval).

Figure 3 uncovers the importance of trade channel through which maximum shock is spilled over to Japan impacting its IRI. Japan is integrated with the global market via trade (Cooper, 2013) ${ }^{17}$. On average, the trade channel explains $43 \%$ of shocks transmission and is followed by the financial channel (38\%) through which external IRI shocks are transmitted to Japan. It further shows that the individual countries such as China (72\%), Germany (58\%), Russia (49\%), and to some extent India (25\%) majorly transmit their shocks to Japan's IRI through trade channel. The financial channel is also quite crucial for Japan because of the significant shock spillover from the U.S (73\%), Germany (36\%), India (27\%), China (23\%), and Russia (32\%) to Japan's IRI. The interesting fact is that the US transmits its shock to Japan through the financial channel, while China passes its shocks to Japan through the

\footnotetext{
${ }^{14}$ Bataa et al. (2018) analysed China's increasing global influence: Changes in international growth linkages.

${ }_{15}^{15}$ Cooper (2013) USA-Japan economic relations: Significance, prospects, and policy options.

${ }^{16}$ IRI stands for composite real interest rate index that framed to capture the overall interest rate shocks spillover from one nation to another nation.

${ }^{17}$ Cooper (2013) has examined US-Japan economic relations: Significance, prospects, and policy options.
} 
trade channel. It is to be recognized that China is also the fastest-growing trade partner of Japan for more than the last two decades (Cooper, 2013).

This result confirms a bi-directional strong financial partnership between the US and Japan through different kinds of capital flows, accounting for a sizeable size of shocks between them. Cooper (2013) also showed that the volume of foreign capital between the US and Japan exceeds their volume of trade. Moreover, trade channel plays an important role when shocks to IRI are transmitted from Germany to Japan and Russia to Japan. This is because Germany and Russia are the important trade partners to Japan, besides China. India is an exception it transmits its shocks to Japan via the exchange rate.

\section{COUNTRIES'IRI->CHANNELS->JAPAN 'S IRI}

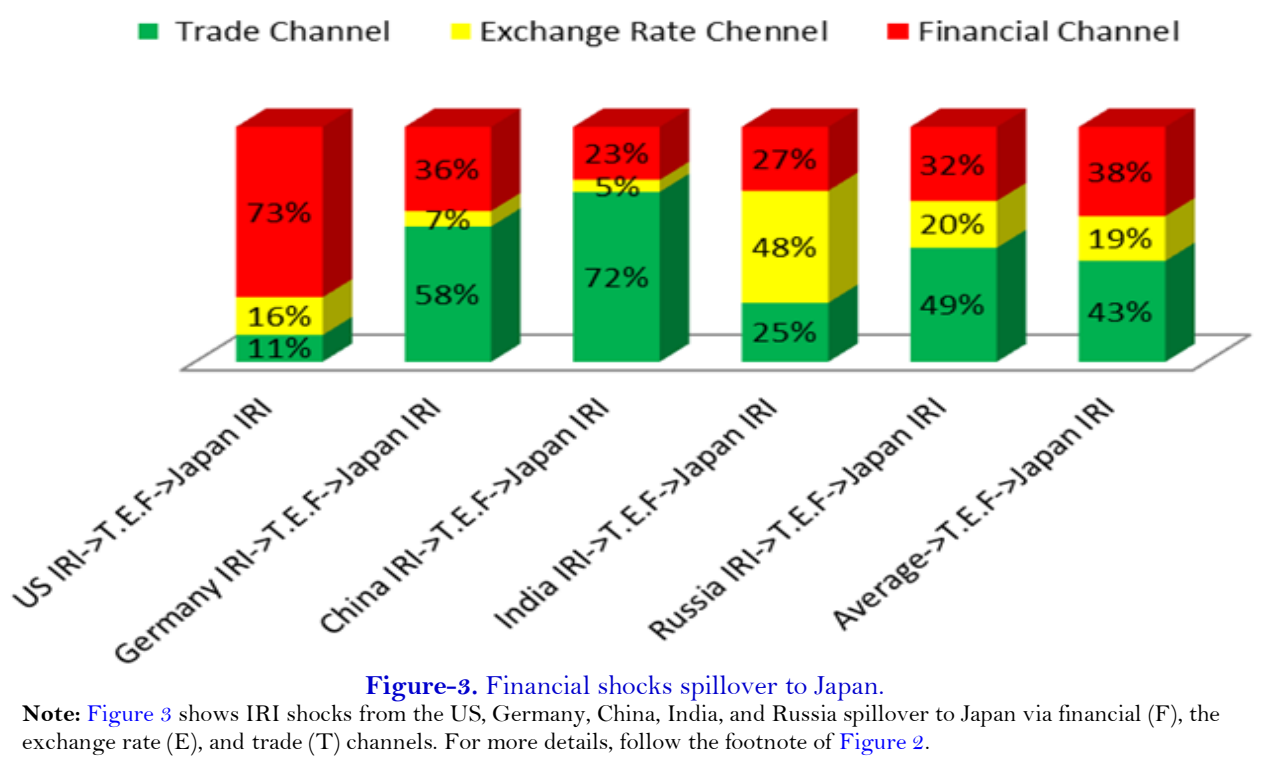

Germany's remarkable trade performance magnifies its integration with the global markets. Germany is a trade surplus economy that enjoys a sizeable share of exports and imports in the world trade. Therefore, it inevitably experiences external shocks from different parts of the world. Figure 4 reflects that the trade channel on average explains $43 \%$ of the variations in Germany's IRI. It can also be visualized from the figure that the size of trade shocks spillover from the US (63\%), China (53\%), Japan (40\%), to Germany, and it is even substantially high from emerging economies like India (32\%), and Russia (27\%).

The highest amounts of shocks spillover to Germany's IRI from the US, China, and Japan take place through trade channel. This sheds light on the importance of their trade linkages between them. The U.S and China are the top destinations for Germany's exports and imports which matter for Germany's IRI. Apart from trade channel, the financial channel also accounts for $37 \%$ of the total external shocks. This shows the importance of the financial linkage of Germany with the global economy. Individually, Russia accounts for $56 \%$ of shocks to Germany via financial channel followed by Japan (49\%), China (35\%), U.S (24\%), and India (19\%). Russia's financial market is also one of the biggest emerging markets like Germany by market capitalization. It provides a strong relation between Russian and Germany's financial markets (Jalolov \& Miyakoshi, 2005). Therefore, this financial integration and strong linkages might be leading to the prospect of a greater propagation of shocks from Russia to Germany via the financial channel. Similarly, around $49 \%$ of shocks spread from Japan to Germany through the financial route. With the greater magnitude of shocks received by Japan from different source economies, India is again found to be an exception which significantly transmits its shocks to Germany only via the exchange rate channel. 


\section{COUNTRIES'IRI->T.E.F->GERMANY'S IRI}

\section{Trade Channel Exchange Rate Chennel E Financial Channel}

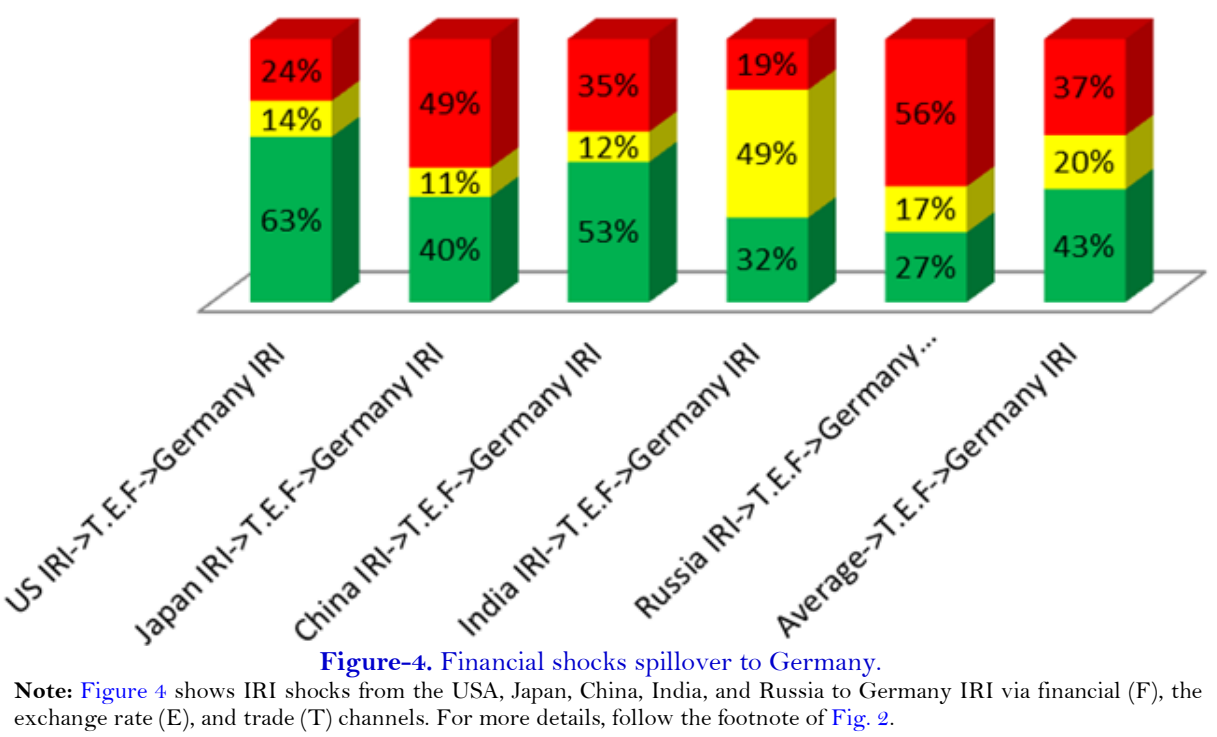

China's rapid rise and remarkable economic growth transformation mark an extraordinary implication not only for its own economy but also for the world. The enormous linkage between China and the rest of the world substantially gets reflected in its share of international trade (Arora \& Vamvakidis, 2011) $)^{18}$. Fig. 5 reflects that on an average $76 \%$ of external shocks are transmitted to China through the trade channel. The role of financial and exchange rate channels is minimal, forming $12 \%$ each. It shows that a major portion of shocks from the USA (61\%), Japan (86\%), Germany $(85 \%)$, India (64\%), and Russia $(87 \%)$ are propagated to China solely through the trade channel. However, the US is an exception that transmits its shocks to China via financial channels. This is because the US being the financial capital of the world can have a potential influence on the financial market of China.

The trade channel affects China's IRI substantially. It is to note that China has been augmenting a network of economic associations with both advanced and developing countries through trade. The US, Japan, Germany, India, and Russia are the top trading partners to China. This result could imply trade integration of China is much stronger than that of the integration with other countries through financial and exchange rate. Therefore, China's trade is playing a major influential role in the global economy (Bataa et al., 2018)19.

Fig. 6 explains the importance of international transmission channels through which it affects India's IRI. It shows that the exchange rate channel explains $74 \%$ of variations in India's IRI, while the financial channel almost plays no role for India. India's real exchange rate movement is found to be quite volatile and sensitive to the external economic factors overtime (Kotai, 2013). This is because, the movements of India's exchange rate, is relatively frequent and there is sharp volatility in the value of Indian Rupee against major currencies of the world such as the US and Euro. The result shows that the US, Japan, Germany, and Russia transmit their shocks to India solely through the exchange rate channel.

\footnotetext{
18 Arora and Vamvakidis (2011) China's economic growth: international spillovers.

${ }^{19}$ Bataa et al. (2018) Analysed China's increasing global influence: Changes in international growth linkages
} 


\section{COUNTRIES'IRI->T.E.F->CHINA'S IRI}

\section{- Trade Channel Exchange Rate Chennel E Financial Channel}
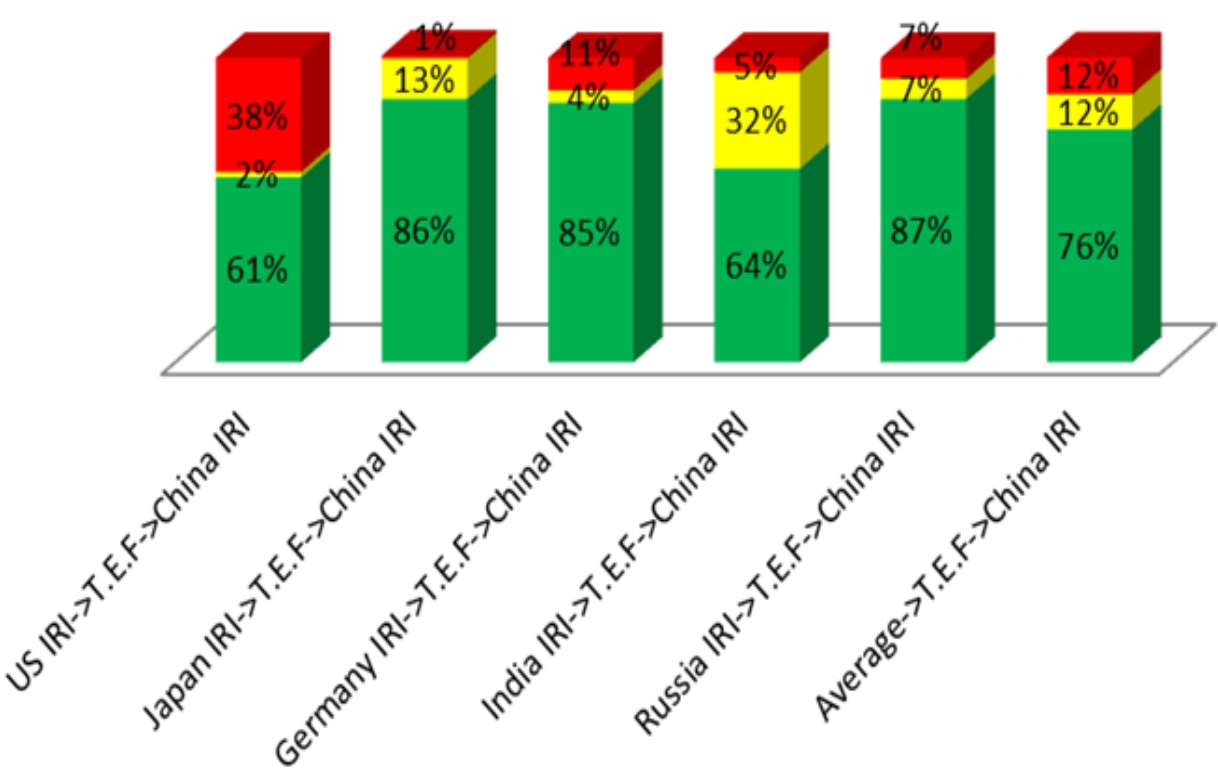

Figure-5. Financial shocks spillover to China

Note: Figure 5 shows IRI shocks from the US, Japan, Germany, India, and Russia to China by financial (F), the exchange rate $(\mathrm{E})$, and trade $(\mathrm{T})$ channels. For more details, follow the footnote of Figure 5.

This is to be recognized that the exchange rate uncertainties in India, affect India's exports and imports, and ultimately the current account balance and private investment (Dhasmana, 2017; Panda \& Mohanty, 2015). China is the exception that it transmits $80 \%$ of its shocks to India via the trade channel as a neighbouring country in the Asian region. It is to emphasize that the working of the trade channel between China and India is not quite surprising as India is a major trade partner of China. Therefore, China transmits a larger magnitude of shocks to India through the trade channel.

Figure 7 provides an understanding of the role of channels through which Russia receives the external shocks to its IRI. It reflects an equal relevance of both trade and financial channels through which $76 \%$ of shocks spillover from external IRI to Russia’s IRI.

The rest of the shocks (24\%) are attributed to the real exchange rate. Examining the individual country shocks, such as Germany (52\%), Japan (52\%), US (50\%), it demonstrates that majorly they explain the variations in Russia's IRI through the trade channel. Surprisingly, the (90\%) of shock spillover from China to Russia takes place purely through the financial channel.

This result is a little surprising because China, in general, transmits its shocks to other countries (to the US, Japan, Germany, and India) via trade channels, while for Russia there is a little deviation. Nevertheless, China is an important and incredible source of financial investment for Russia, which may account for the highest transmission of shocks from China to Russia through the financial channel. By contrast, shocks spillover from India's IRI to Russia’s IRI via the exchange rate channel is still 59\% which is quite substantial and this is a common channel as far as India's shock propagation is concerned for all other economies. 


\section{COUNTRIES'IRI->T.E.F->INDIA IRI}

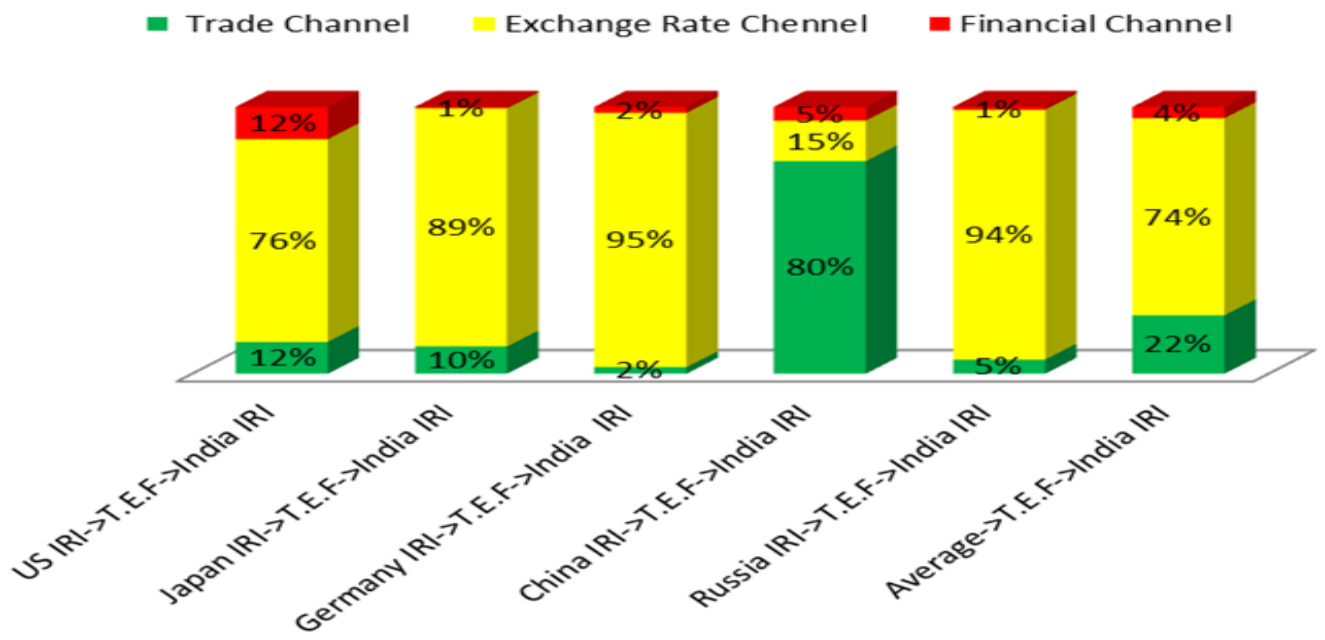

Figure-6. Financial shocks spillover to India.

Note: Figure 6 shows IRI shocks from the US, Japan, Germany, China, and Russia to India via financial (F), the exchange rate (E), and trade $(\mathrm{T})$ channels. For more details, follow the footnote of Figure 2.

\section{COUNTRIES'IRI->T.E.F->RUSSIA'S IRI}

\section{- Trade Channel Exchange Rate Chennel Einancial Channel}

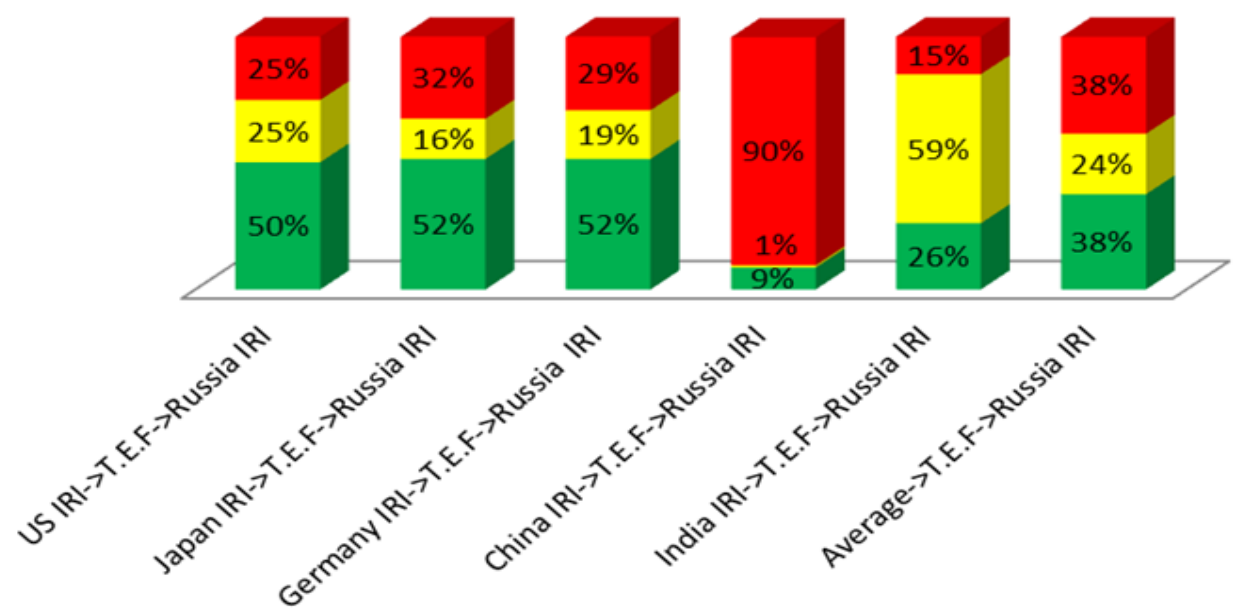

Figure-7. Financial spillover to Russia.

Note: Figure 7 shows IRI shocks from the US, Japan, Germany, China, and India to Russia via financial (F), the exchange rate $(\mathrm{E})$, and trade $(\mathrm{T})$ channels. For more details, follow the footnote of Figure 2.

\section{CONCLUSION}

The previous studies neither provided a complete and clear-cut insight on the extent of spillover nor identified how financial shocks propagate or spillover through different channels between advanced and emerging countries. Although few studies attempted to examine the shock transmission from the developed countries to developing countries' markets, they were unidirectional and did not provide any insight into the transmission of financial shocks in the reverse direction. Therefore, by aiming to assess the extent of spillover and relative importance of judging various channels through which financial shocks in form of interest rates transmit among the US, Japan, and Germany, China, India, and Russia, this study tried to fill up the research gap and thereby it contributes to the international financial transmission of shocks literature. At first, it employed Diebold and Yilmaz (2009); Diebold and Yilmaz (2012) method, to assess the extent of spillover. The result demonstrated that a high variation (i.e. $43.6 \%)$ in IRI is due to the mutual response of financial markets among these countries. Thus, the total spillover is observed to be quite significant. Further, we found the advanced countries play a greater role in influencing financial markets than some of the emerging countries. In fact, advanced countries often dominate markets in terms 
of the generation of shocks for other economies. Therefore, the contribution of advanced countries for heightening volatility in emerging countries is indispensable and this finding is observed to be empirically robust and more convincing even by changing the model specification.

Using the orthogonal impulse response of a restricted VAR model, we tried to analyse the relative strength of channels through which financial shocks spillover from one country to another. It shows that on an average $46 \%$ of the external financial shocks spillover to the US via the financial channel. However, the importance of the trade channel is evident through which maximum external IRI shocks (on average) spread to Japan, Germany, and China and in turn, affecting their real interest rates. In particular, it is observed that the trade channel mainly dominates in the transmission of the external shocks, when external interest rate shocks are transmitted to Japan, Germany, and China. Conversely, India's interest rate receives major external interest rates shocks through the exchange rate channel. However, the result also demonstrates the equal relevance of both the combination of trade and financial channels through which more than $76 \%$ of the shocks spillover from external sectors to Russia's interest rates.

The empirical findings of the study have significant policy bearing. This is in light of the issues of crosscountry financial shocks spillover which have been gaining significant international policy concerns especially in the context of greater financial market integration of economies in this $21^{\text {st }}$ century and thereby raising all possible expectations of economic crises building up more frequently in uncertain times given the history of financial crises engulfing the economies or regions over time. This understanding of specific spillover channels through which shocks spillover from one country to another is very much essential as it would boost macroeconomic policy implementation for the US, Japan, Germany, China, India, and Russia. Diebold and Yilmaz (2015) pointed out the right assessment of shocks spillover is fundamental for the successful implementation of macroeconomic policy. Therefore, identifying the important channels through which external financial shocks spillover among the countries, can help the policymakers to frame suitable macroeconomic policies to mitigate various economic uncertainties and instabilities.

The drawbacks of this analysis are; first, this analysis is limited to six countries. Second, the study of the relative strength of channels is not based on empirical robustness check although the extent of spillover is found to be robust. Third, this study does not address the degree of spillover (both pairwise and total spillover) evolving overtime as it is over a specific period. This is because the study is based on fewer observations. It requires further research in the future which can be extended based on these above drawbacks as outlined.

Funding: This study received no specific financial support.

Competing Interests: The authors declare that they have no competing interests.

Acknowledgement: Both authors contributed equally to the conception and design of the study.

\section{REFERENCES}

Ahmad, W., Mishra, A. V., \& Daly, K. J. (2018). Financial connectedness of BRICS and global sovereign bond markets. Emerging Markets Review, 2018(37), 1-16. Available at: https://doi.org/10.1016/j.ememar.2018.02.006.

Al Awad, M., \& Goodwin, B. K. (1998). Dynamic linkages among real interest rates in international capital markets. Journal of International Money and Finance, 17(6), 881-907. Available at: https://doi.org/10.1016/so261-5606(98)00032-1.

Anoruo, E., Ramchander, S., \& Thiewes, H. F. (2002). International linkage of interest rates: Evidence from the emerging economies of Asia. Global Finance Journal, 13(2), 217-235.

Arora, V., \& Vamvakidis, A. (2011). China's economic growth: International spillovers. China \& World Economy, 19(5), 31-46. Available at: https://doi.org/10.1111/j.1749-124x.2011.01257.x.

Artis, M. J., \& Zhang, W. (1998). The linkage of interest rates within the EMS. Weltwirtschaftliches Archiv, 134(1), $117-132$. Available at: https://doi.org/10.1007/bfo2707581. 
Bastidon, C., Bordo, M., Parent, A., \& Weidenmier, M. (2019). Towards an unstable hook: The evolution of stock market integration since 1913 (No. w26166). National Bureau of Economic Research.

Bataa, E., Osborn, D. R., \& Sensier, M. (2018). China's increasing global influence: Changes in international growth linkages. Economic Modelling, 74, 194-206. Available at: https://doi.org/10.1016/j.econmod.2018.05.014.

Bayoumi, T., \& Swiston, A. (2009). Foreign entanglements: estimating the source and size of spillovers across industrial countries. IMF Staff Papers, 56(2), 353-383.

Caporale, G. M., Carcel, H., \& Gil-Alana, L. (2017). Central bank policy rates: Are they cointegrated? International Economics, 152, 116-123. Available at: https://doi.org/10.1016/j.inteco.2017.06.001.

Căpraru, B., \& Ihnatov, I. (2012). Interest rate transmission and exchange rate arrangements in the Central and Eastern European countries: evidence from the current international financial crises. Procedia-Social and Behavioral Sciences, 58, 1273-1282. Available at: https://doi.org/10.1016/j.sbspro.2012.09.1110.

Chang, M.-J., \& Yi, S. C. (2015). Does real interest rate parity really hold? New evidence from G7 countries. Economic Modelling; 47, 299-306. Available at: https://doi.org/10.1016/j.econmod.2015.03.005.

Chinn, M. D., \& Frankel, J. A. (1995). Who drives real interest rates around the Pacific Rim: the USA or Japan? Journal of International Money and Finance, 14(6), 801-821. Available at: https://doi.org/10.1016/0261-5606(95)00038-0.

Ciner, C. (2011). Eurocurrency interest rate linkages: A frequency domain analysis. International Review of Economics $\mathcal{F}^{2}$ Finance, 20(4), 498-505. Available at: https://doi.org/10.1016/j.iref.2010.09.006.

Cooper, W. H. (2013). US-Japan economic relations: Significance, prospects, and policy options. Paper presented at the Library of Congress, Congressional Research Service.

Cumby, R. E., \& Mishkin, F. S. (1986). The international linkage of real interest rates: The European-US connection. Journal of International Money and Finance, 5(1), 5-23. Available at: https://doi.org/10.1016/0261-5606(86)90047-1.

Davydov, D., \& Vähämaa, S. (2013). Debt source choices and stock market performance of Russian firms during the financial crisis. Emerging Markets Review, 2013(15), 148-159. Available at: https://doi.org/10.1016/j.ememar.2013.01.001.

Dhasmana, A. (2017). Impact of exchange rate volatility on investment: Evidence from India. IIM Bangalore Research Paper, No. 533.

Diebold, F. X., \& Yilmaz, K. (2009). Measuring financial asset return and volatility spillovers, with application to global equity markets. The Economic Journal, 119(534), 158-171. Available at: https://doi.org/10.1111/j.1468-0297.2008.02208.x.

Diebold, F. X., \& Yilmaz, K. (2012). Better to give than to receive: Predictive directional measurement of volatility spillovers. International Journal of Forecasting, 28(1), 57-66. Available at: https://doi.org/10.1016/j.jfforecast.201 1.02.006.

Diebold, F. X., \& Yilmaz, K. (2015). Trans-Atlantic equity volatility connectedness: US and European financial institutions, 2004-2014. Journal of Financial Econometrics, 14(1), 81-127.

Dutton, M. M. (1993). Real interest rate parity new measures and tests. Journal of International Money and Finance, 12(1), 62-77. Available at: https://doi.org/10.1016/0261-5606(93)90010-9.

Edwards, S. (2010). The international transmission of interest rate shocks: The Federal Reserve and emerging markets in Latin America and Asia. Journal of International Money and Finance, 29(4), 685-703. Available at: https://doi.org/10.1016/j.jimonfin.2010.01.003.

Feldkircher, M., Huber, F., Chantapacdepong, P., \& Punzi, M. T. (2017). The transmission of interest rates shocks to Asia: Are effects different below the zero lower bound? ADBI Working Paper Series (No. 690).

Forbes, K. J. (2010). Why do foreigners invest in the United States? Journal of International Economics, 80(1), 3-2 1.

Frankel, J., Schmukler, S. L., \& Serven, L. (2004). Global transmission of interest rates: Monetary independence and currency regime. Journal of International Money and Finance, 23(5), 701-733.

Fujihara, R. A., \& Mougoué, M. (1996). International linkages between short-term real interest rates. The Quarterly Review of Economics and Finance, 36(4), 45 1-473. Available at: https://doi.org/10.1016/s 1062-9769(96)90045-9.

Fukao, M., \& Okubo, T. (1984). International linkage of interest rates: The case of Japan and the United States. International Economic Review, 25(1), 193-207. Available at: https://doi.org/10.2307/2648874. 
Goodwin, B. K., \& Grennes, T. J. (1994). Real interest rate equalization and the integration of international financial markets. Journal of International Money and Finance, 13(1), 107-124. Available at: https://doi.org/10.1016/0261-5606(94)900272.

Hassler, U., \& Werkmann, V. (2012). New panel evidence on international interest rate linkage. Retrieved from: SSRN: https://ssrn.com/abstract=2194831 or http://dx.doi.org/10.2139/ssrn.2194831. [Accessed December 30, 2012].

Jalolov, M., \& Miyakoshi, T. (2005). Who drives the Russian financial markets? The Developing Economies, 43(3), $374-395$.

Kirchgässner, G., \& Wolters, J. (1987). US-European interest rate linkage: A time series analysis for West Germany, Switzerland, and the United States. The Review of Economics and Statistics, 69(4), 675-684. Available at: https://doi.org/10.2307/1935963.

Koop, G., Pesaran, M. H., \& Potter, S. M. (1996). Impulse response analysis in nonlinear multivariate models. Journal of Econometrics, 74(1), 119-147. Available at: https://doi.org/10.1016/0304-4076(95)01753-4.

Kotai, V. (2013). An empirical study on currency volatility in foreign exchange market. Global Journal of Management and Business Studies, 3(8), 897-904.

Lütkepohl, H. (2011). Forecasting aggregated time series variables: A survey. OECD Journal: Journal of Business Cycle Measurement and Analysis, 2010(2), 1-26.

Mark, N. C. (1985). Some evidence on the international inequality of real interest rates. Journal of International Money and Finance, 4(2), 189-208. Available at: https://doi.org/10.1016/0261-5606(85)90043-9.

Merrick Jr, J. J., \& Saunders, A. (1986). International expected real interest rates: New tests of the parity hypothesis and US fiscal policy effects. Journal of Monetary Economics, 18(3), 313-322. Available at: https://doi.org/10.1016/03043932(86)90043-7.

Mohan, R., \& Nandwa, B. (2009). Examining interest rate linkages among ASEAN-5, China and India. ASEAN Economic Bulletin, 26(2), 174-179. Available at: https://doi.org/10.1355/ae26-2c.

Monadjemi, M. S. (1997). International interest rates linkages: Evidence from OECD countries. International Review of Financial Analysis, 6(3), 229-240.

Nier, E. W., \& Merrouche, O. (2010). What caused the global financial crisis? Evidence on the drivers of financial imbalances 1999-2007.

OECD/JRC. (2008). Handbook on constructing composite indicators: Methodology and user guide. Paris: OECD Publishing.

Panda, S., \& Mohanty, R. K. (2015). Effects of exchange rate volatility on exports: Evidence from India. Economics Bulletin, 35(1), 305-312.

Pesaran, H. H., \& Shin, Y. (1998). Generalized impulse response analysis in linear multivariate models. Economics Letters, 58(1), $17-29$.

Pigott, C. (1993). International interest rate convergence: A survey of the issues and evidence. Federal Reserve Bank of Nerw York Quarterly Review, 18(4), 24-37.

Probst, J. (2019). Global real interest rate dynamics from the late 19th century to today. International Review of Economics $\mathcal{E}^{\circ}$ Finance, 2019(59), 522-547. Available at: https://doi.org/10.1016/j.iref.2018.10.016.

Sowmya, S., Prasanna, K., \& Bhaduri, S. (2016). Linkages in the term structure of interest rates across sovereign bond markets. Emerging Markets Review, 2016(27), 118-139. Available at: https://doi.org/10.1016/j.ememar.2016.05.001.

Takáts, E., \& Vela, A. (2014). International monetary policy transmission. BIS Paper No. 78b, Available at SSRN: https://ssrn.com/abstract=2498133.

United Nation. (2019). World economic situation and prospects (WESP), 2019.

Urbina, J. (2013). Financial spillovers across countries: Measuring shock transmissions. MPRA Paper No. 75756 . Retrieved from: https://mpra.ub.uni-muenchen.de/ 75756 . 


\section{APPENDIX}

The study examines the properties of the time series of all variables by conducting the seasonality test, unit root test, and structural break test. Taking care of properties of time series provides us the right result rather than misleading ones. The data series are seasonally adjusted by using the X-12-ARIMA model. The stationarity problem is verified by conducting the Augmented Dickey-Fuller (ADF) test. All the stationary time series data are used at the time of estimation of the specific model used in the present study.

\section{Stability Results of the Estimated Model of IRI}

Fig.-A 1 reflects no root lies outside the unit circle with optimum lag 3 as per Akaike Information Criteria (AIC) which satisfies stability of the estimated model.

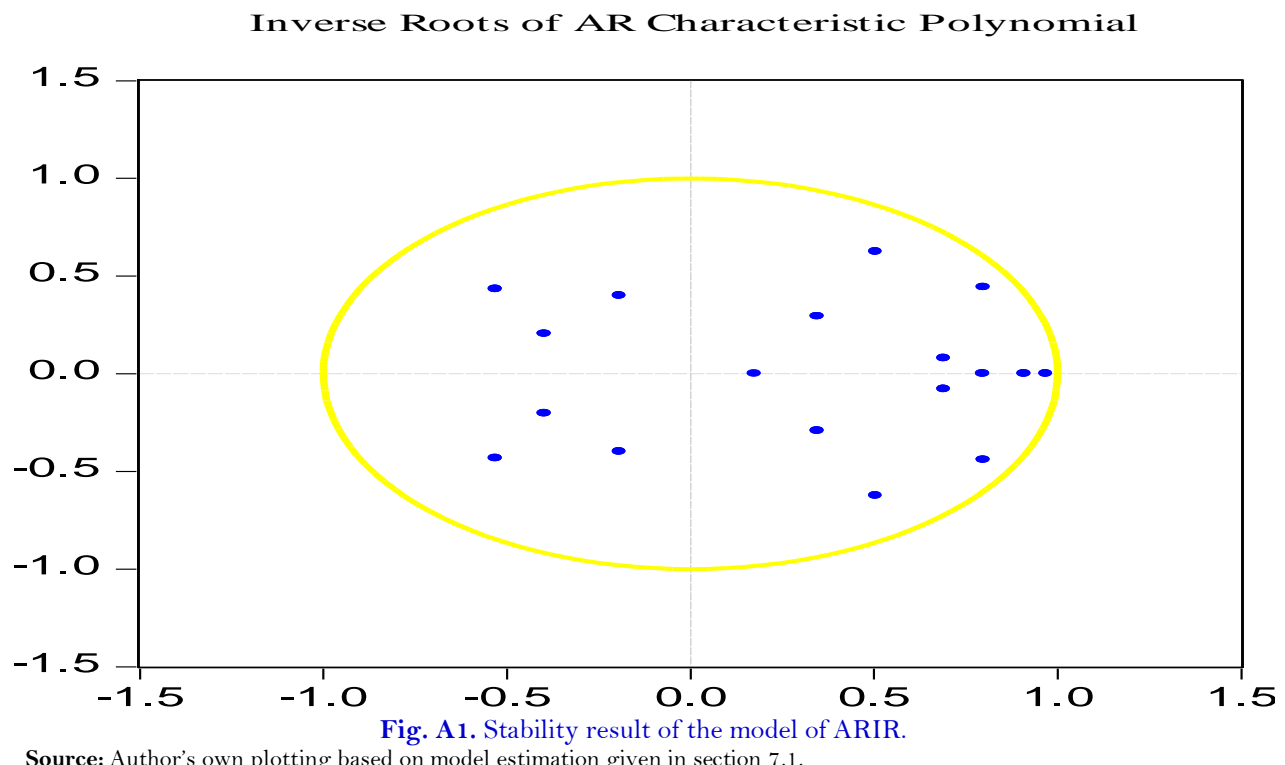

2. Stability Result of Estimated Model for Robustness Check

Inverse Roots of AR Characteristic Polynomial

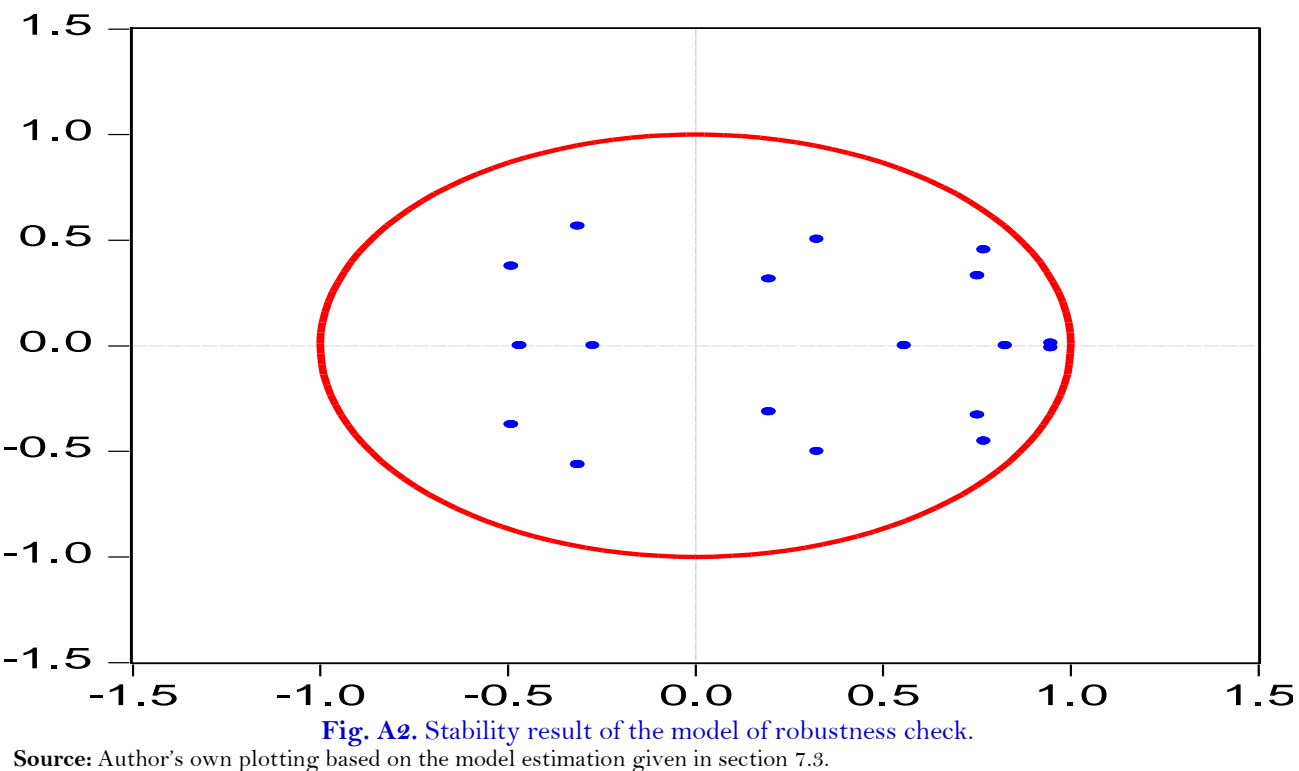

Source: Author's own plotting based on the model estimation given in section 7.3 . 
Fig. A2 reflects the estimated model for the robustness check. It is stable as no root lies outside the unit circle with optimum lag 3 as per AIC.

Table A2. Spillover table for robustness check.

\begin{tabular}{l|l|l|l|l|l|l|l}
\hline Variables & US & Japan & Germany & China & India & Russia & From Others \\
\hline US & 55.4 & 14.1 & 13 & 13.1 & 3.5 & 0.9 & 44.6 \\
\hline Japan & 12.1 & 58.3 & 7 & 5.9 & 14.8 & 1.9 & 41.7 \\
\hline Germany & 18.4 & 10.8 & 64.8 & 3.8 & 1.2 & 1 & 35.2 \\
\hline China & 22.4 & 6.6 & 1.7 & 60.6 & 3.7 & 4.9 & 39.4 \\
\hline India & 9.1 & 18.6 & 8.6 & 6 & 50 & 7.8 & 50 \\
\hline Russia & 13.1 & 28.1 & 1.6 & 7.5 & 11.8 & 37.9 & 62.1 \\
\hline to others & 75.1 & 78.3 & 31.9 & 36.2 & 35 & 16.5 & 273.1 \\
\hline including own & 130.4 & 136.6 & 96.7 & 96.8 & 85 & 54.5 & $45.50 \%$ \\
\hline Net & 30.5 & 36.6 & -3.3 & -3.2 & -15 & -45.6 & \\
\hline
\end{tabular}

Note: The spillover table-A2 estimated through Diebold and Yilmaz methods of spillover which is based on generalized forecast error variance decomposition of 10 quarters ahead horizon with optimum lag 3 as per AIC.

Views and opinions expressed in this article are the views and opinions of the author(s), Asian Development Policy Review shall not be responsible or answerable for any loss, damage or liability etc. caused in relation to/arising out of the use of the content. 